\title{
Cõi tạm
}

\author{
Khúc Văn Quý
}

February 7, 2021

Preprint DOI: https://osf.io/nerh5/

Nếu có khổ thì sống vui vì được tu trong cõi đời gian thế Nếu có vui thì sống lặng vì được may trong cõi tạm thôi mà

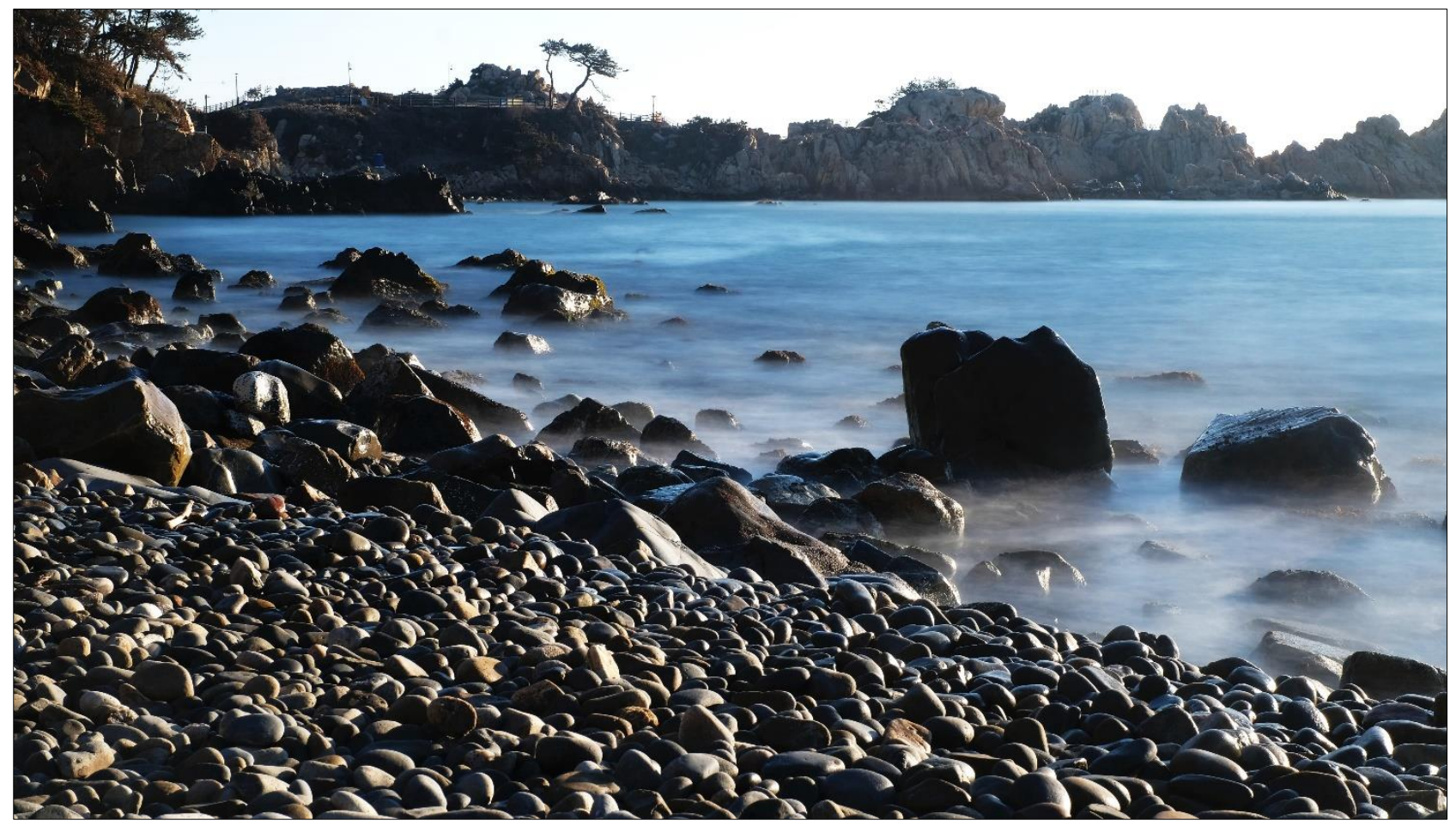

(C2020 photo courtesy: Trung Tran 